Article

\title{
Acoustic Comfort in Learning Spaces: Moving Towards Sustainable Development Goals
}

\author{
Isabel Montiel ${ }^{1,2, *}$, Asunción M. Mayoral ${ }^{2,3} \mathbb{C}^{\text {, }}$, Jose Navarro Pedreño ${ }^{4, *}$ and Silvia Maiques 5 \\ 1 Conselleria de Educació, Generalitat Valenciana, 03007 Alicante, Spain \\ 2 Department of Statistics, Mathematics and Informatics, Universidad Miguel Hernández, 03202 Elche, Spain \\ 3 University Institute of Research CIO, Universidad Miguel Hernández, 03202 Elche, Spain \\ 4 Department of Agrochemistry and Environment, Universidad Miguel Hernández, 03202 Elche, Spain \\ 5 Technical Department at CIEGSA (Educational Building and Infraestructures), Generalitat Valenciana, \\ 46018 Valencia, Spain \\ * Correspondence: imontiel@umh.es (I.M.); jonavar@umh.es (J.N.P.)
}

Received: 14 May 2019; Accepted: 24 June 2019; Published: 28 June 2019

check for updates

\begin{abstract}
The association between learning spaces and new pedagogical approaches is a current issue. Research shows that the classical, more silent, master class is being bypassed by student centered methods with participative classes and active methodologies. Major efforts in teacher training are taken to help teachers implement these new approaches in their lessons. The conditions of the learning space are also influential. The following question is raised: Can acoustic comfort facilitate innovation and consequently help in the progress towards SDG? We have focused on public high schools in Spain (IES), in the Valencian Community. Data has been gathered from the visit to thirty high schools. International scientific studies and valid guidelines referring to noise have been reviewed. Findings on the research conclude that acoustic comfort is essential in education and is directly related with the implementation of emerging pedagogies. Likewise, the outcomes of the investigation hope to raise awareness among authorities and civil society that improvement of sound quality in learning spaces facilitates the achievement of sustainable development goals (SDG), particularly those concerning goal 3 (health and wellbeing), goal 4 (quality education) and goal 9 (sustainable infrastructures).
\end{abstract}

Keywords: educational innovation; active methodologies; learning spaces; space design; acoustic comfort; sustainable development goals

\section{Introduction}

Student centered methods with participative classes are narrowing the gap between the methodology used in education and labour market challenges as society is moving towards a more sustainable development.

We strongly believe in the words cited in the Spanish Education for Sustainability Report published in 2017 "A school that promotes education for sustainable development is a community that teaches for the future, is part of a complex culture, uses critical thinking, clarifies values, that lives and experiences the environment and acts responsibly seeking sustainability. As a result, it offers an innovative education, in which the organization is examined, as well as the operation and management, democratic participation, methodology and role of the teachers, and consequently, fosters cooperation with local, regional or global nets" [1] (p. 10).

We also support the commitment with the Agenda 2030 and the importance of moving towards sustainable development goals (SDG). This specific study concerns targets corresponding to SDG3 (health and wellbeing), SDG 4 (quality education) and SDG 9 (sustainable infrastructures). Through active and participatory methods, we are promoting a work philosophy that listens to the community, 
and stands on values and attitudes that encourage change towards more sustainable development outcomes [2,3].

However, we are currently witnessing that in spite of teacher training in order to expand active methods, on site, in the classroom, obstacles arise and bottlenecks appear. Very often, these challenges are related to the building environment. Only recently the connection between the physical features of the environment and its effects on user's performance [4-6], frame of mind and emotional states of the students [7], even discipline and behavior issues [8] have started gaining momentum. Even more recent is the relationship between spaces and the effects on teachers' health and conduct [9].

There is a broad international consensus on the virtues of active methodologies and how these encourage more sustainable outcomes. It is our objective to raise awareness amongst the educational community and decision makers in the planning and design of schools that optimal sound insulation is needed and proper sound absorbing materials should be used in construction and refurbishment of learning spaces [7].

This article about acoustic comfort is part of a wider research aimed at contributing useful guidelines so educational spaces become facilitators of the work and achievements of students and teachers. Thus, the building itself and the constructed school environment take an active role in transforming educational methodologies and helping implement an education for sustainable development [10]. If we are supporting active methods to guarantee the achievement of SDG, what is the role of acoustics? Do we have suitable conditions? Are learning spaces adequately conditioned regarding acoustic comfort (proper insulation, optimal wall, floor and ceiling coverings in order to avoid reverberation, appropriate location within the school, etc.)?

The next step is to investigate the weaknesses of classroom conditions and the relation between them and the implementation of new active methodologies, which produce necessarily more noise. Twenty first century methodologies no longer focus on only one person, the teacher, who imparts knowledge to pupils while they listen and learn in silence. Nowadays, the new strategies, more so, with young and adolescent students cause "noise", specially to users of adjacent rooms, who may be a lot older.

New pedagogical approaches inspire teachers, at all levels of education, to implement techniques that diverge from the classical master class. Active learning strategies and methodologies such as cooperative learning, design thinking, learning by doing, flipped classroom, use of ICT to produce, project-based learning-ABP, learning and service projects, inquiry-based learning and different uses of mobile devices are student-centered methods endorsed by competencies in the four C's: Communication, collaboration, creativity and critical thinking [11].

Some of the questions that support our research concern physical space and involve more directly architects, engineers and designers: Are acoustic conditions favorable in classrooms (even for traditional methodologies)? Others regard new ways of learning and teaching: Are acoustic conditions acceptable for certain new methods? Can acoustic discomfort limit or slow down teachers' urge to implement innovative strategies? Others refer to health issues: Does the need to battle background noise cause throat problems, temporary voice loss, and other physical, emotional or mental problems in teachers or students? They all lead to the key question: Can acoustic comfort facilitate innovation and consequently help in the progress towards SDG?

\section{Materials and Methods}

Our research has focused on public Institutos de Enseñanza Secundaria (IES), public high schools, in the Valencian Community in Spain. It is advisable to clarify certain details about the functioning system of these schools. Figure 1 describes a brief outline of the education provided at a Spanish high school. These schools in most of the cities of the Valencian Community administer a wide spectrum of educational levels: Enseñanza Secundaria Obligatoria (ESO), Advanced Secondary education (Baccalaureate) and vocational studies (Formación Profesional -FP-). Most schools enroll about one thousand students. The age of students is also wide ranging," somewhere between 12-13 years of age, for first year secondary education and over 40 in some cases for vocational study students. The most 
numerous age bracket being from 12 to 16 year olds, which is compulsory secondary education. The teaching methods and interests, of both teachers and pupils, of the different levels very often diverge.

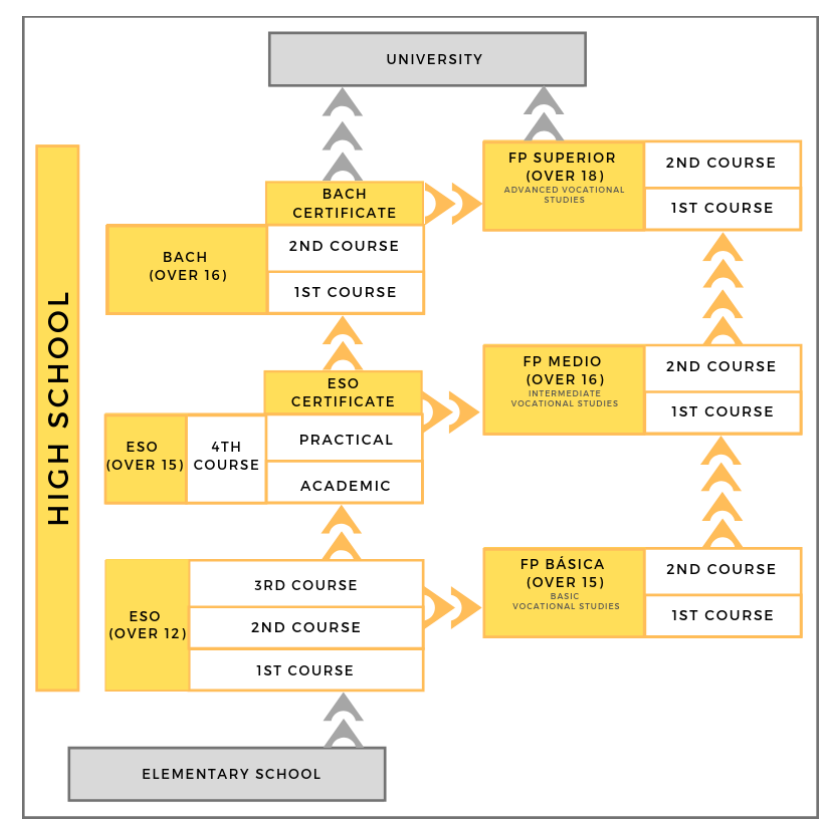

Figure 1. Brief outline of the Spanish Secondary Education System. Source: Compiled by the authors based on current legislation.

The questions posed for the research have led to carrying out the investigation in different phases and by implementing varied methodology. Information gathered for this paper is summarized in Figure 2 and explained below.

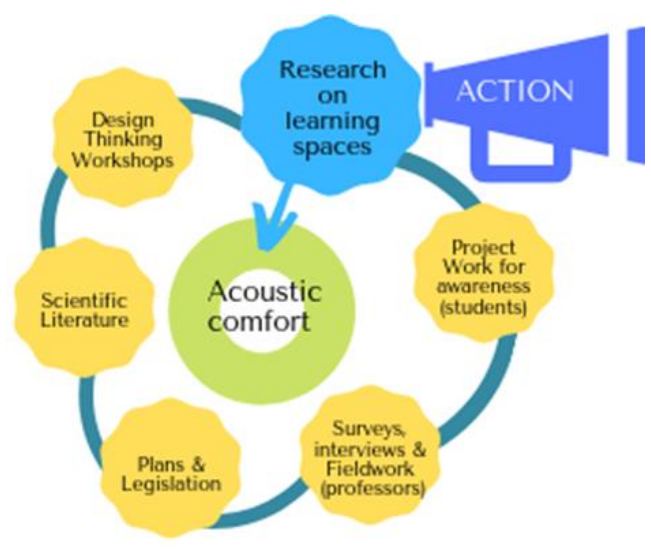

Figure 2. Various information sources considered for the research.

- $\quad$ SCIENTIFIC LITERATURE. There is a broad consensus in the international community regarding the advances that the design of spaces implies for educational improvement, as seen in the scientific literature consulted. National and international scientific studies included in referenced journals have been reviewed, as well as referenced conference proceedings. Books published since 2010 about learning spaces and reports available online were consulted. The keywords used for the search were: Acoustic comfort, noise in schools, sustainable development goals, learning spaces, school design, and participatory approaches. Science direct and Google Scholar engines were used to find articles. Once the articles were selected, references were looked over to identify other relevant studies. In this second search, we preferred papers, which had been made available through open access publications. 
- PLANS \& LEGISLATION. Regulations for the construction of public secondary schools in the Valencian Community have been consulted, as well as the floor plans of twenty high schools. The report, which was sent to the Inspection of Education [12] after the inauguration of IES Mediterrània of Benidorm (Alicante) in 2007, can be considered as the initial concern for this investigation.

- DESIGN THINKING WORKSHOPS. We are aware of the importance of participatory approaches in an education for sustainable development education. Therefore, we have promoted and attended design thinking processes for the planning of university learning spaces. Outcomes of these workshops [13] are easily comparable with high school requirements and therefore have been used in point four of this paper to contribute to solutions and suggestions.

- PROJECT WORK FOR AWARENESS. Students were involved in projects implementing a methodology of participatory action research in order to raise awareness of noise issues and highlight that we all need to be part of the solution. An example of these activities is the video mentioned in Section 3.2 "Architects, Help!" [14].

- SURVEYS, INTERVIEWS AND FIELDWORK. We have visited thirty schools in the Valencian Community, mainly in the province of Alicante and conducted individual and collective interviews to principals and teachers. Furthermore, a structured survey, about the efficiency of learning spaces was sent to teachers of the high schools in the province of Alicante. The Educational Authorities of Alicante (Dirección Territorial de Educación de Alicante) have been informed of the ongoing investigation. Gathering of statistical data and indicators supplied by surveys, interviews and visits to IES occurred between July 2018 and March 2019, although other informal school tours and interviews had been taking place for an extended period of time.

Interviews. A total number of twenty-two directors were interviewed using a face-to-face semi structured interview [15], that is, previously prepared questions, but that can be adjusted or new ones added according to the participants' answers. One hundred percent of the public high schools in the city of Elche (Alicante), fifteen in total, participated in the study. The duration of each interview and the school tour that followed lasted between one and a half to two hours.

S Survey. The day after the interview, an online structured questionnaire, specific for teachers, was sent for the principal of the high school to pass on to the staff. This tool provided the investigation with feedback from teachers concerning conditions of the spaces they use as well as the methodologies they implement. It also gives specific information concerning the subject each teacher lectures teaches with a differentiation between academic subjects, taught in standard classrooms and practical ones, which use specific classrooms or workshops. For this particular paper, only the answers concerning acoustics in standard classrooms were considered, 147 responses in total. The findings are summarized later in this article. See Figure 3 for distribution of subjects.

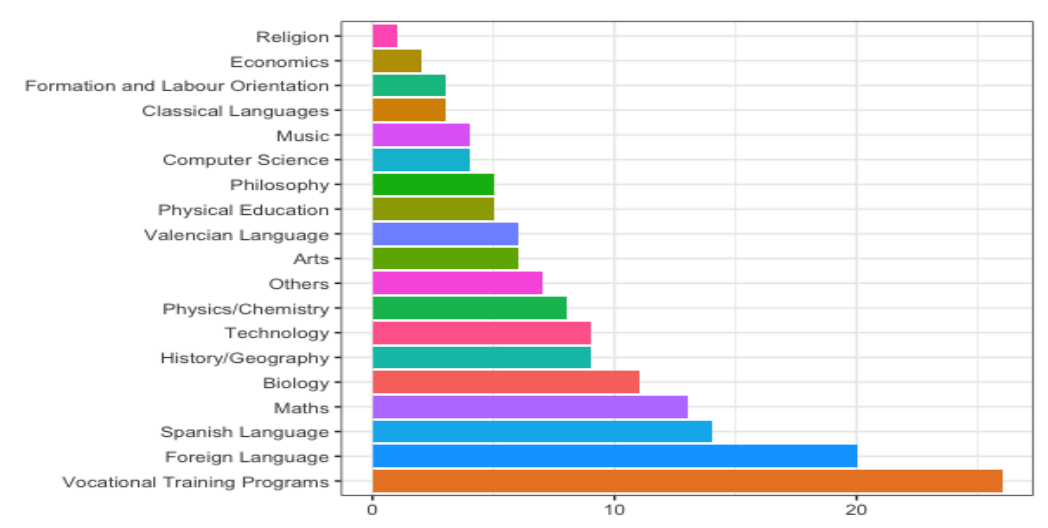

Figure 3. Distribution of responses to questionnaire according to subjects. 
With respect to the statistical methodology used to analyze the data, the significance level is set to $95 \%$. To compare proportions, we use a z-test and to compare means we use a Student-t test, which is available in common statistical bibliography.

\section{Findings and Discussion}

\subsection{Findings Obtained from Scientific Review}

\subsubsection{Negative Effects of Noise in Schools}

Studies consulted agree upon the fact that poor acoustics or noise that comes from within or outside of the classroom interferes with student's learning and hinders teacher's ability to continue with instruction [7,16-19]. Working in the presence of a continuous background noise affects academic performance $[20,21]$. Some authors argue that even if acoustic pollution did not have a direct effect on academic performance, health issues should be considered of major importance [7,22].

Measurements carried out in primary and secondary schools in Finland [24], Sweden [17], Brazil [25], Iran ([21]), The United States [20] Turkey [26] and Perú [27] show that schools are exposed to greater noise levels than recommended. In some cases, causes of this noise pollution are due to external factors such as, air traffic or highway noise, but it is more common that the noises come from activities that take place from within the school such as, music, sports, games, engaging dynamics, lunchrooms [7]. According to data from the Department of Education of the Basque Government in school dining halls, comparable to cafeterias in high schools, the average level of decibels can reach 85 decibels (dB), going up to $100 \mathrm{~dB}$ in many instances. According to law [28], in classrooms, noise levels should be under $40 \mathrm{~dB}$ (see Table 1). Acoustic quality noise levels inside buildings according to their use during daytime (Ld), afternoon (Le) or night (Ln) is shown in Table 1 [23]. A comparative level of sounds is displayed in Table 2 [29].

Table 1. Acoustic quality goals for noise levels inside buildings for residential use, hospitals, schools and cultural centers. References for 1.2 to 1.5 m height. Retrieved from Royal Decree 1367/2007, 19 October [23].

\begin{tabular}{ccccc}
\hline \multirow{2}{*}{ Use of the Building } & Type & \multicolumn{3}{c}{ Noise Level (L) } \\
\cline { 2 - 5 } & & L Day & L Afternoon & L Night \\
\hline \multirow{2}{*}{ Residential use } & Living areas & 45 & 45 & 35 \\
\cline { 2 - 5 } & Bedrooms & 40 & 40 & 30 \\
\hline \multirow{2}{*}{ Hospitals } & Siting areas & 45 & 45 & 35 \\
\cline { 2 - 5 } & Bedrooms & 40 & 40 & 30 \\
\hline \multirow{2}{*}{ Schools and cultural } & Classrooms & 40 & 40 & 40 \\
\cline { 2 - 5 } & Reading rooms & 35 & 35 & 35 \\
\hline
\end{tabular}

The distraction that is created in noisy environments alters cognitive performance [5]. Unfavorable acoustic conditions not only affect oral comprehension, but also written comprehension and expression, due to the reduced ability to concentrate and remember facts. "The 9 Foundations of a Healthy Building" [16] is a study conducted in 2017 by a multidisciplinary team of experts from Harvard University working with a program to develop healthy buildings. This research verifies that noise causes distraction and interferes with students' learning and can affect cognitive development, especially in children younger than 15 years, who are still in the process of developing language skills. Furthermore, students with special needs, such as attention deficit disorder or hearing loss suffer from more severe uneasiness due to noise disruption $[5,30]$.

It is admitted that the discomfort that is generated by noise not only limits concentration and attention, which causes physical stress and fatigue due to the tension that it creates, but also produces 
psychological stress, causing people to feel irritable or frustrated. Furthermore, psychological stress and irritation due to noise can be the reason behind incidents in the classroom $[8,16]$. A relationship has been observed between annoyance caused by persistent noise and an increase in disruptions that create discipline issues [20]. It can also induce professional dissatisfaction and uneasiness amongst teachers, making them feel reluctant to incorporate more engaging dynamics.

Table 2. Comparative table of the level of common sounds, expressed in A-weighted decibels $(\mathrm{dB}(\mathrm{A}))$ [29].

\begin{tabular}{ll}
\hline \multicolumn{2}{c}{ COMPARATIVE TABLE OF DECIBELLS } \\
\hline Birds singing & $20 \mathrm{dBA}$ \\
\hline Rustling of the wind in trees & $25 \mathrm{dBA}$ \\
\hline Reading room & $35 \mathrm{dBA}$ \\
\hline Computer & $45 \mathrm{dBA}$ \\
\hline Conversation between two people & $55 \mathrm{dBA}$ \\
\hline Vacuum cleaner & $70 \mathrm{dBA}$ \\
\hline Office (10 people) & $75 \mathrm{dBA}$ \\
\hline Garbage truck & $85 \mathrm{dBA}$ \\
\hline Road traffic & $90 \mathrm{dBA}$ \\
\hline Car horn & $95 \mathrm{dBA}$ \\
\hline Bus horn & $100 \mathrm{dBA}$ \\
\hline Disco music & $110 \mathrm{dBA}$ \\
\hline Motorcycles & $115 \mathrm{dBA}$ \\
\hline Hydraulic drill & $120 \mathrm{dBA}$ \\
\hline Jet airplane takeoff & $140 \mathrm{dBA}$ \\
\hline
\end{tabular}

Moreover, background noise forces teachers to raise their voice 10-15 dB above normal conversation level [31]. Physiological intensity of the voice at normal conversation level is equal to or lesser than 60 decibels. This means that a teacher speaks at a level of at least $70 \mathrm{~dB}$ during a good part of the day. This situation causes work-related disorders, such as loss of voice (according to the Spanish Federation of Education Workers, $22 \%$ of Spanish teachers suffer voice loss), sore throat, nodules $[9,30,32]$ or even mental fatigue, anger and irascibility $[16,18]$.

\subsubsection{Practical Compared to Academic Subjects}

Research confirms that certain subjects do not face noise issues the same way as others. A contrast exists between "practical" and "academic" subjects. Practical subjects are those taught traditionally in workshops, labs or specific classrooms, while academic subjects are instructed in standard classrooms [21]. Subjects that are taught in spaces equipped for workshops (technology, art) laboratories (physics and chemistry, biology, natural sciences) sports (physical education), and computer classes implement a more engaging methodology and do not face noise disruptions the same way as other academic areas. Academic subjects are the most adversely affected by noise disruptions. According to studies conducted in Sweden in students from ages 12 to 14, the results in reading comprehension tests were higher in quieter classrooms [31]. The results of the math tests, which were carried out in the United States, also show lower grades in classrooms where there were higher noise levels [20].

It is important to highlight this fact, seeing that in Spain these two subjects, mathematics and language are considered key subjects for promoting from one year to the next in Enseñanza Secundaria Obligatoria (ESO-Compulsory Secondary Education). That is, a student in ESO can be promoted to 
the following level having failed two subjects, as long as they are not mathematics and language [33]. This is important for obtaining the Certificate in Compulsory Education. According to information from the National Statistics Institute (INE) for data of 2017, Spain has a very high school drop-out rate $(18.9 \%)$, whereas the average for the $\mathrm{EU}$ is $10.7 \%$.

\subsubsection{A Participatory Approach}

A participatory appraisal is necessary [34-36] to solve problems concerning learning spaces and to avoid repeating future construction errors due to the lack of knowledge about teaching methodologies on the planners' part.

Awareness is growing amongst architects and engineers on the need to bear in mind that problems created by poor acoustics are difficult to solve after the basic design phase of the building and specially have a greater economic cost $[4,37,38]$. For the purpose of a proper planning and design of a school, it is necessary to know first-hand the use that each space will have [37], and for this reason we should turn to participatory processes [34-36]. Particular efficiency is being demonstrated by the methodology of design thinking [13,39-41].

Furthermore, countries that exemplify educational innovation, such as Finland, are starting to establish multidisciplinary commissions to evaluate the design of new schools as well as to advise on the renovations of existing ones in order to provide optimal learning space quality $[7,29]$. These commissions are convincing authorities to include conclusions of their studies in specific legislation for school building construction $[7,22]$. Therefore, the infrastructure itself becomes an ally in the development of methodologies based on collaborative work and facilitates the learning process [10].

\subsection{Findings Obtained from Plans and Legislation}

The Noise Pollution Protection Act. (Law 7/2002, 3 December, Generalitat Valenciana) [28] states that "Noise, contemplated as an undesired sound by the listener or an unpleasant and annoying sound, is nowadays a cause of concern as a result of its effects on health and human behavior, individually and as a group; examined the physical, psychological, and social consequences." Noise is a key indicator of environmental quality. It is an acoustic pollution and therefore, greater noise generates a lower quality of life [42].

Thereby, the need for acoustic comfort is gaining significance. Both from the education sector to environmental agencies, steps are being taken to educate citizens about the negative effects and highlighting that noise pollution affects our health and wellbeing. Various cities in Spain have developed programs along these lines. Madrid, for example, created in 2005 the educational program "Educar para vivir sin ruido" (Educating for life without noise) [43]. This program offers guided teaching approaches to work on activities in primary and high schools to engage everyone in the community to take action and control the noise in their immediate surroundings, schools, neighborhoods, and homes. Inside schools, initiatives are also being undertaken, as seen in the projects carried out by 1st ESO students at IES San Miguel de Meruelo in 2013 [44] or in the video "Architects help!", produced by 2nd ESO students at IES Mediterrània in Benidorm in 2017 [14].

The side effects that buildings have on people are, fortunately, a growing concern. Research shows that the building environment has repercussions on people's health as well as on work performance. The Building Ordinance Act (38/1999 of the 5th of November-LOE-La Ley de Ordenación de la Edificación) [45] passed in 1999, is a state level law. It covers educational and cultural buildings and includes guidance in order to improve the user's well-being. Article 3 defines the basic building requirements as related to functionality, security and habitability. In the latter, sound protection is included; it establishes that users should be able to carry out their duties successfully and that noise should not put a person's health at risk.

The uneasiness that noise pollution creates occupies one of the top issues in the list of concerns in modern communities. Nowadays, it is increasingly common to refer to the IEQ (Indoor Environment Quality) level of a building [46]. This concept includes elements such as noise, thermal comfort, indoor 
air quality and even visual comfort. The ambient quality is related to higher productivity [31,47]. Furthermore, guides are being published for architects which include recommendations for sustainable construction such as: LEED (Leadership in Energy and Environmental Design) [48] or GSAS (Global Sustainability Assessment System) [49]. Although in educational buildings there is still, a lot of ground to be covered [37].

In Spain, the Technical Building Code (Código Técnico de la Edificación) [50], passed in 2006 and subject to continuous changes, is the current framework, which is mandatory to comply. The Technical Building Code regulates the basic quality demands of buildings, which are included in the Building Ordinance Act. It is composed of a General Part and a series of Basic Documents: Structural integrity, fire safety, use and accessibility safety, energy savings, and health and noise protection.

The approval of the Technical Building Code has meant a qualitative leap in regard to the way insulations are viewed in Spain. The Basic Document of Noise Protection (Documento Básico de Protección contra el ruido) included in the Technical building code [50] was modified in 2016. Its objective is to establish rules and procedures to limit the risk of sickness and discomforts that noise pollution can cause in the people who occupy the buildings. According to this document, the construction materials should satisfy the appropriate noise characteristics in order to reduce airborne sound transmission, reduce the noise caused by impacts, reduce the noise caused by vibrations from the building's mechanical equipment, and, finally, limit the noise caused by reverberations in every area of the building. Compliance with this Document ensures minimum levels of quality for the basic requirements of noise protection.

This Basic Document of Noise Protection, also a state law, is what determines the sound criteria for the construction of the high schools in the Valencian Community. However, this document determines, mainly, the minimum insulation needed to protect interior spaces from noises caused by external sources and has been modified as recently as 2016, all the schools subject to study were built before that date. Architects are required to take data from city noise maps, which give information about the intensity of the sound that is produced in each area and each street of the city. According to this information and using different charts from the Basic Document of Noise Protection, the amount of necessary insulation is calculated. For example, insulation for facades fluctuates between 33 and 53 decibels, depending on the city map for outside noise.

Regarding the interior spaces, when designing a school, each space should be classified according to its use, for example, premises such as classrooms and offices are considered to produce a noise (R) less than 70 decibels. Other activity premises such as music rooms, workshops, cafeterias are considered to produce a noise level between 70 and 80 decibels.

Areas classified for instructional purposes (classrooms, multi-purpose rooms, offices, departments and the library) are designated as protected spaces. Upon studying the charts of the Basic Document of Noise Protection, these areas should be insulated from each other for at least $50 \mathrm{dBA}$ (A-weighted decibels). Between a protected area, a classroom for example, and a mechanical room, such as the boiler room, they should be insulated from at least a level of $55 \mathrm{dBA}$. Additionally, anti-impact iron sheets must be placed on the roof to insulate from impact caused by noise. Moreover, vibrations from the mechanical equipment should be reduced with shock absorbers which absorb the movements produced by the equipment in order to avoid the noise being transmitted to the rest of the building.

In the Construction Plan of a school, a report on the buildings' compliance with the Basic Document of Noise Protection must be included. Furthermore, once construction has begun, it must be supervised meticulously in order to control materials' reception and to assure they are quality materials. Attention to detail and good construction should be closely monitored to avoid "sound bridges." Once construction is finished, noise studies should be conducted on the premises to guarantee the compliance of sound protection in classrooms and protected areas. All in all, according to law, acoustic comfort should be guaranteed.

However, there are no specific guidelines in the regulations that indicate that school sport fields or playgrounds should be located away from classrooms, nor that music rooms should be placed on 
the highest floor of the building, away from protected areas or maybe, even outdoors. Nor are there directives, which state that the cafeteria or gym should be in a different building than the classrooms. These seem to be left to good common-sense practices of the planners.

The Spanish Basic Document of Noise Protection [50] has, mainly, the goal to protect the premises from external noise (street). This fact should be changed and noise within the school should have the same consideration.

We find that noise pollution in high schools is due to the use of low-quality soundproofing elements, or even the use of materials that increase reverberations [7], or due to a lack of planning as seen in the layouts of Figures 4 and 5.

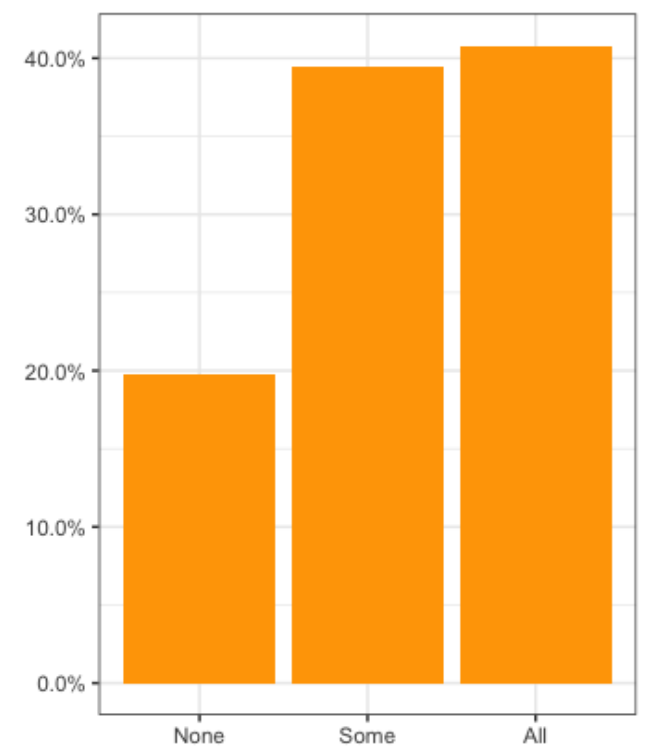

(a) No reverberation or echoes.

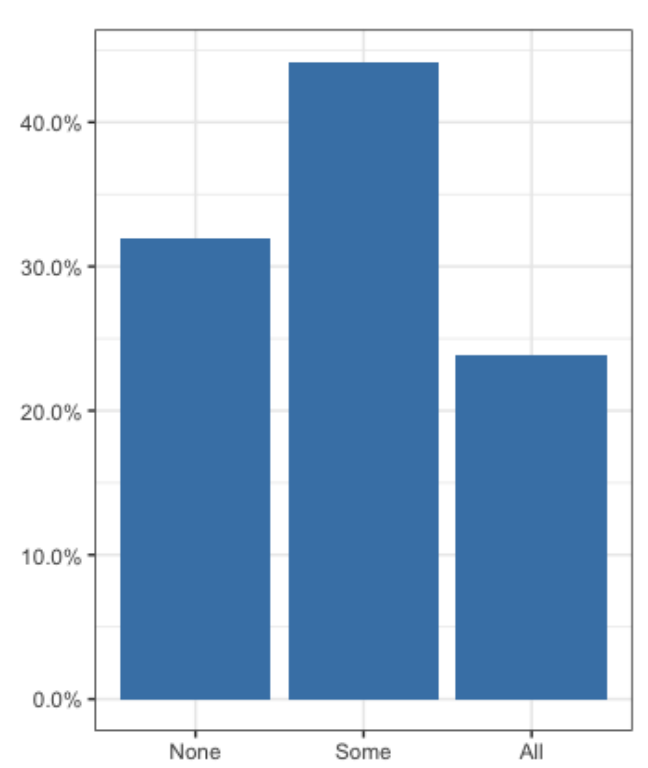

(b) Minimum noise from outside.

Figure 4. Results from the structured survey to teachers about the acoustic conditions of the classrooms. (a) Percentage of teachers that indicate the absence of reverberation or echoes in none, some or all of the classrooms they teach in; (b) percentage of teachers that indicate minimum noise/disruption from outside in none, some or all of the classrooms they teach in.

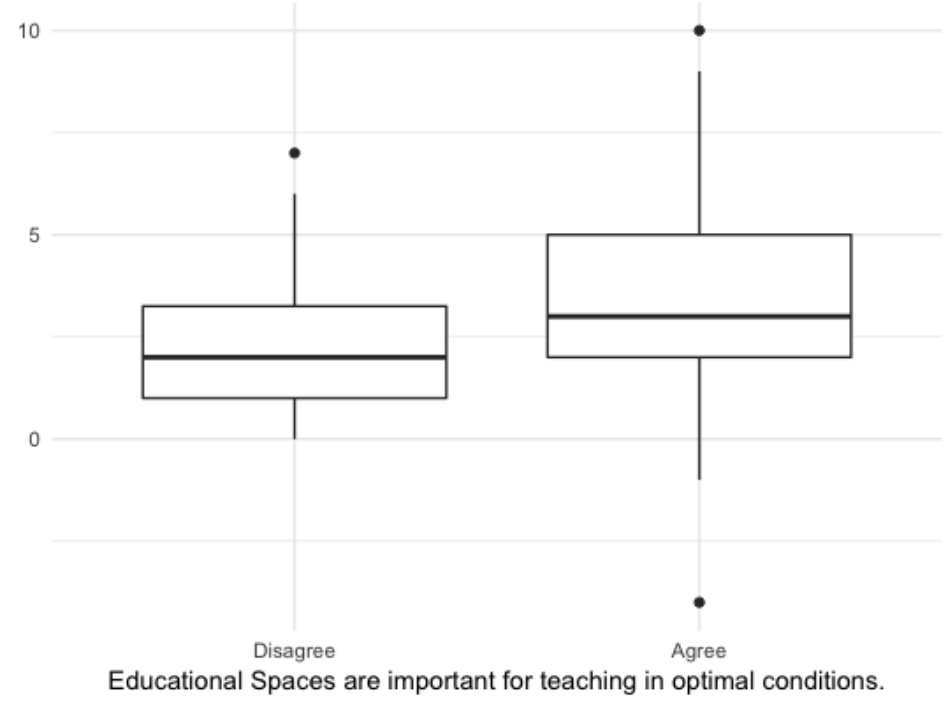

Figure 5. Willingness to apply active methodologies if space conditions improve. 


\subsection{Findings Obtained from Field Work, Interviews and Survey}

\subsubsection{Findings from the Teachers' Questionnaire}

A structured survey, about the efficiency of learning spaces was sent to the high schools in the province of Alicante. The questions regarding acoustic comfort in the classroom were the following:

- Are the acoustic conditions of the classrooms in which you teach acceptable (There is no reverberation or echo)?

- p096. Are noises from outside or adjacent spaces minimum (they do not cause disruption/discomfort)?

Figure 4a shows the percentage of teachers that indicate that none; some or all the classrooms they teach in have reverberations and echoes. Twenty percent say in none of the spaces the acoustic comfort is acceptable, $39 \%$ indicate that only in some spaces and $41 \%$ say there are no reverberations or echoes in all the spaces where they work.

Figure $4 \mathrm{~b}$ illustrates the percentage of teachers that point out that in none, some or all the classrooms they teach in the noise from outside is minimum. Thirty-two percent admit that in none of the classrooms noise is minimum, $44 \%$ say in only some rooms it is minimum, if we add these two results, we can conclude that $76 \%$ feel discomfort due to outside noise, and only $24 \%$ acknowledge acoustic comfort in all the rooms they teach in.

$p$-values for z-test are considerably lower than 0.05 (significance 95\%):

- $\quad p$-value $=4.353 \times 10^{-6}$ concerning acoustic conditions inside the rooms (tiling, shape, structure)

- $\quad p$-value $<2.2 \times 10^{-16}$ regarding insulation from outside noise or adjacent rooms.

Thus, we can affirm that most teachers do not feel acoustic comfort in classrooms, both for internal conditions as for noises coming from outside. Statistical evidence is significant.

Regarding the question can acoustic discomfort limit or slow down teachers' urge to implement innovative strategies? Two aspects considered in the questionnaire respond to this research question:

- How important do you consider a better conditioning of learning spaces in order to perform in optimal conditions. Teachers were asked to answer on a scale from one to five. Although this inquiry does not directly refer to acoustics it has a direct relation to it. The results were categorized in two levels: Those who value the need of better conditioning positively (rate 4 and 5 measured on the Likert scale) or negatively (rate 1,2, and 3).

- How would teachers use active methodologies in optimal working conditions in relation with the methods they are using currently? Each rating (actual and optimal use) was collected on a scale from 0 to 10, therefore the difference is on a scale between $(-10,10)$. Positive rates identify a proactive attitude towards the incorporation of active methodologies providing optimal conditions were given in the school.

We resolve our question through a Student-t test with an alternative hypothesis: "those teachers that recognize the need of good conditioned spaces (and therefore good acoustic conditions) are more motivated to move on towards using active methodologies than those who don't care about educational spaces (or acoustic conditions)". Differences are shown in Figure 5, and clearly significative given a p-value of 0.037 for the Student- $t$ test. Thus, we verify that the implementation of active methodologies is restricted by the space conditions, in which acoustic comfort is included.

\subsubsection{Music Rooms}

The case of the Music subject in ESO requires particular attention in Valencian Community, a region of strong musical tradition. Not until 1990 when the LOGSE Education Act took effect, was music a noise issue. Before then, very few high schools had music teachers. The subject of music was more theoretical and philosophy and humanities teachers would teach concepts about the history of 
music; instruments were rarely or never used, with the exception of, sometimes, the recorder. However, since then and ever so gradually, musicians who hold a degree required for teaching music classes have joined the faculty at current high schools. Nowadays, there is also a more practice-based music curriculum. Through new methodologies students are invited to bring out their inner talent and to participate in projects and concerts, rehearsed in class, but performed in the local community or even internationally through Erasmus programs. Furthermore, some of these projects are based on community and learning-service approaches pursuing sustainable development objectives, as is the event that is held at the Hospital General Universitario de Alicante (Universitary General Hospital of Alicante) by Special Educational Needs students [14]. With such activities, values are promoted through action, not only by conceptual means.

Even though the music curriculum for the ESO is broad and not only limited to playing instruments, it is obvious that practice, rehearsal and performances raise student's motivation and levels of self-esteem. The sound of the instruments due to lack of soundproofing causes discomfort in adjacent rooms. Interviews confirm that the discontent is more prevalent among teachers of academic subjects, given that part of their lessons require greater concentration and silence for exercises. Such is the case in foreign language comprehension and expression, writing in history, philosophy, reading comprehension in any language, calculating and problem solving in mathematics.

As there are no regulations about the location of music classrooms, cases such as those seen in Figure 6 can occur. The building of the IES Mediterrània in Benidorm was inaugurated in 2007. It was designed for 1000 students and 90 teachers. The school was constructed with two non-soundproofed music classrooms on the main floor of the central building and larger in dimensions than other classrooms, which makes it difficult to find another location for these spaces. According to facts from the interview conducted with the principal in June 2018, the school has invested more than 30.000 euros trying to soundproof the space, but it has not been very effective. It's not only the financial cost but a growing tension and a feeling of powerlessness on the affected teachers that makes the situation problematic.

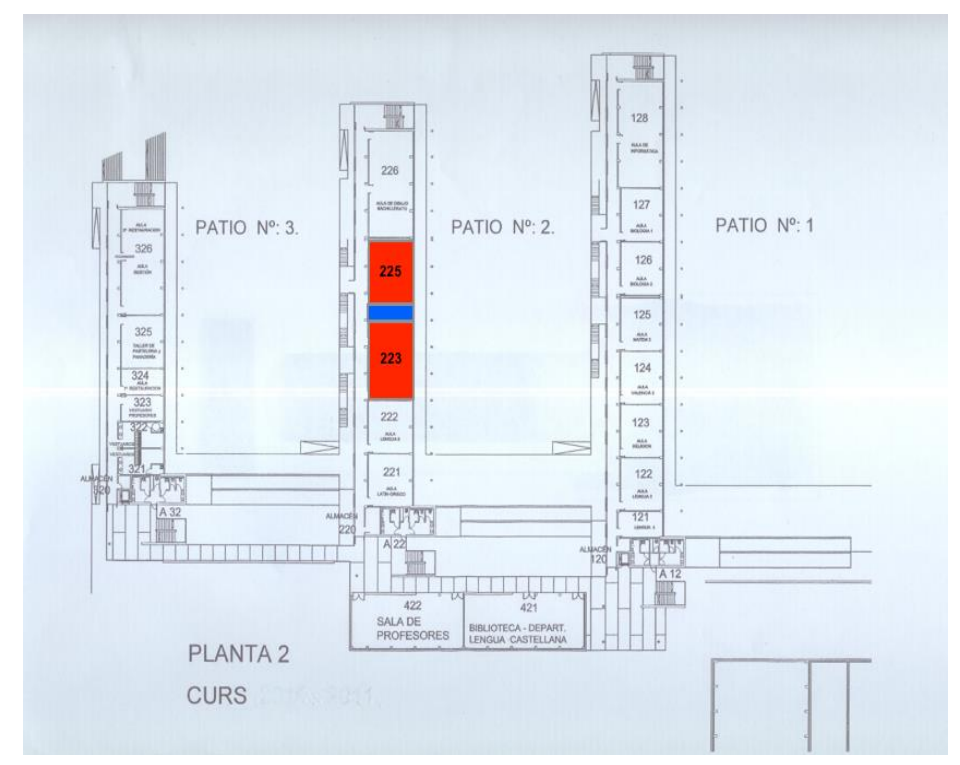

Figure 6. Music rooms (223 and 225) in the center of the school premises.

Truth-be-told, this is the only school where we have observed this situation. However, the uneasiness caused by this mistake, declared by teachers and students, reaches such an extent that it is important to be aware of this fact for future school planning and construction. 


\subsubsection{Foreign Languages}

Emerging methodologies promote increased verbal communication in the foreign language classroom by both the professors and students. Students are expected to interact between classmates and the teacher, as well as conduct oral presentations in the target language in order to achieve sustainable development goals. Oral expression in the language is considered equally as important as oral comprehension. With the latter, one must bear in mind the importance of audio transmission devices and the need of clear sound and little reverberation. Teachers that give instruction in a language that is not the mother tongue of the students, state that they require spaces in which the acoustics of the learning environment have been carefully taken into consideration. One hundred percent of the foreign language teachers (nine English teachers and three French teachers) interviewed at IES Mediterrània claim difficulties in their subject due to the noise from other activities in the school, mainly music rooms and sport fields. See Figure 7.

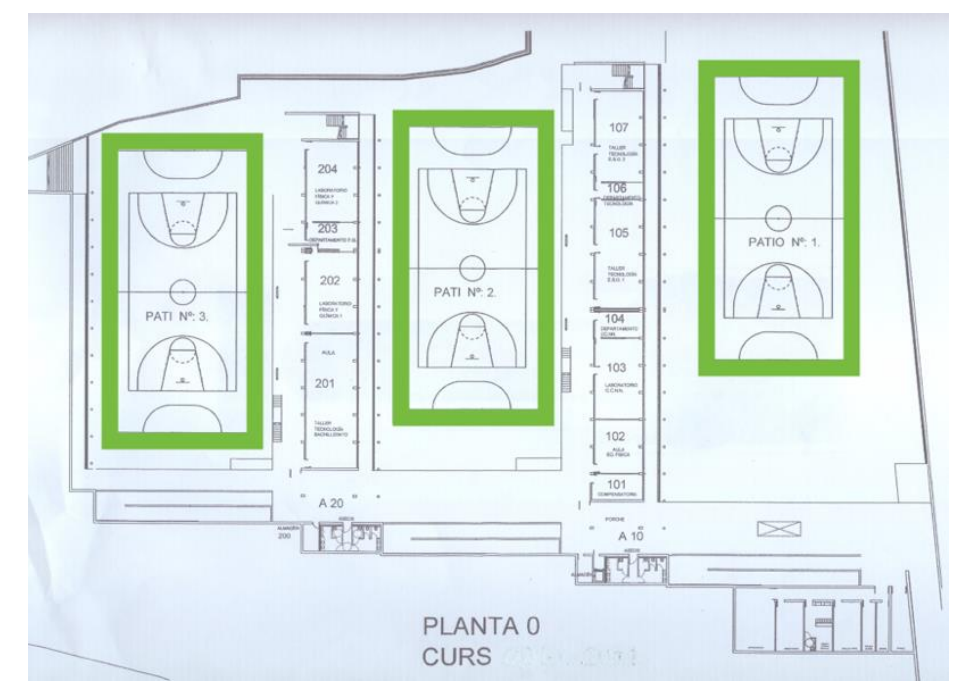

Figure 7. All classroom facades facing sport fields.

\section{Recommendations and Conclusions}

\subsection{Recommendations}

Following are a number of solutions that emerged from the analysis of scientific literature, outcomes of design thinking workshops, conclusions of field trips to the school premises, or findings collected from surveys and interviews with teachers. They are suggestions belonging to a sustainable development education approach that would definitely, contribute to an improvement of acoustic comfort in learning spaces.

We have divided the ideas into three categories according to an estimated financial cost.

\subsubsection{Category I. High Financial Cost}

The first category includes ideas concerning the building design. They would avoid errors that indicate a lack of vision on the part of the planners or little knowledge of the current educational uses of the spaces. These mistakes are difficult to solve once the building construction has finished or represent a substantial investment after construction and should not be charged on the school's budget.

The following are important recommendations:

- It is advisable to plan sources of noise "pollution", such as playgrounds, sport fields or music rooms, not facing or adjacent to classrooms or libraries [7] as seen in Figures 6 and 7.

- Heating and ventilation ducts are noise conductors. Shared systems should be avoided in order to prevent noise interference [51]. 
- The geometry of space also influences acoustic comfort. In rooms that are narrow, sound bounces back from the walls generating reverberation and acoustic discomfort to the users [37], therefore square spaces are more acoustically comfortable.

- Vertical ceramic tiling or huge glass windows increase reverberation. The echoing of sound is worse when walls, floors and ceilings are not porous. It has been observed, in certain schools, that they have added porous elements, for example, sound-absorbing ceiling or covering vertical paneling with cork, and this has improved greatly the sound quality in the room.

- Classroom doors should not face each other [25].

- It is strongly recommended that a guide be written specifically for high schools, with instructions on where to position the noisiest spaces, bearing in mind that in IES in Spain, adult education and young students share the same premises and once the building is occupied structural changes are difficult and expensive.

\subsubsection{Category II. Medium Cost}

These measures do not require major structural changes, they are cost effective solutions, advisable even in buildings already in use.

- Insulate rooms with double glazed windows.

- Light sources and air conditioning units for libraries, reading and study rooms should be especially silent [20].

- Music rooms should keep windows closed at all times when playing instruments. In the SE of Spain air conditioning would be required in such cases. This choice does not contradict the previous point, as activities conducted in these premises are usually louder than the level of noise produced by air conditioning units.

- An idea noticed at IES Tirant lo Blanc, Elche, was to equip certain instruments in the music room with headsets for individual rehearsals.

- Impact-absorbing materials should be used in interior decoration on walls, ceilings, floors and windows in order to avoid reverberation [20,25,37]. Adding internal curtains or blinds to the windows helps both for solar protection and acoustic comfort.

- In high schools, designing at least one Foreign Language lab would be sensible, properly insulated and equipped with quality loudspeakers for reproducing listenings, video conferences and videos of native speakers. This solution is just a matter of interior design of a standard classroom.

- For the purpose of avoiding the noise that is generated from moving desks and chairs every 55 minutes, it is advisable to install felt or rubber studs under chair and desk legs $[7,26]$ or arrange timetables of certain classrooms for longer periods of active methodologies. This is the measure that has been adopted at IES Cayetano Sempere in Elche, where teachers that more often use project work are assigned to certain rooms.

- In the same line as mentioned above, a specific area for project work, co-working, thinking-lab, as seen in Figure 8, could be adapted for the use of general academic subjects, which are usually taught in standard classrooms. Again, this is a matter of interior design not structural changes.

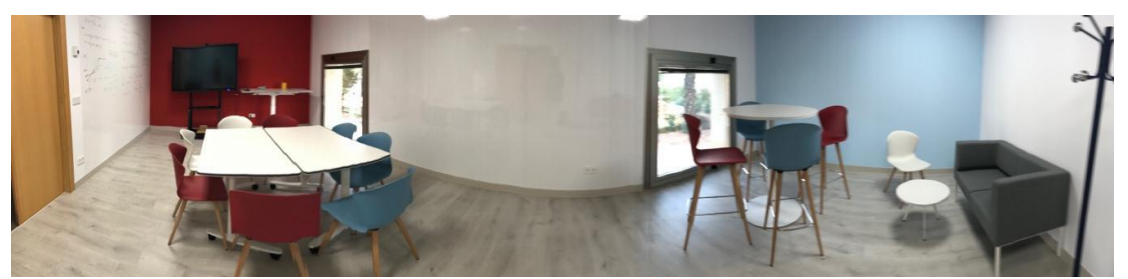

Figure 8. Example of a Thinking Lab, consequence of a participatory appraisal at University Miguel Hernández, 2019. 


\subsubsection{Category III. Low Cost}

This third category includes recommendations that not always need a significant financial investment. They are solutions backed up by neuroscientists. Studies in neuroscience have confirmed that our brain reacts to certain stimuli $[52,53]$. These studies suggest the need to generate friendly, comfortable spaces and pleasant sounds, areas with views, close to or in contact with natural or artificial nature.

- It is recommended to replace the siren or bell indicating the end of the lesson by music [26]. In 12 of the 30 schools evaluated this measure has been implemented, in some cases involving students and making them responsible for the type of music chosen for the occasion. Loudspeaker systems should be tested and function correctly for a better operation of this solution.

- Studies verify that working in offices with tables in "open-planning" increase distraction. In these areas they suggest the use of plants as barriers, soft music or nature sounds in order to improve concentration [17]. Very few of the schools evaluated have silent rooms for teachers to correct papers, prepare lessons or do research. Most teachers express that they work at home or in the main teachers' room under conditions that are not favorable for concentration.

- Open spaces also have advantages but it is necessary to create privacy for certain activities, such as personalized tutoring or private parent meetings. One hundred percent of the principals interviewed claimed lack of space, and therefore declare to optimize corners in corridors or other areas and make them suitable. Some companies design special furniture for these purposes, as the example in Figure 9.

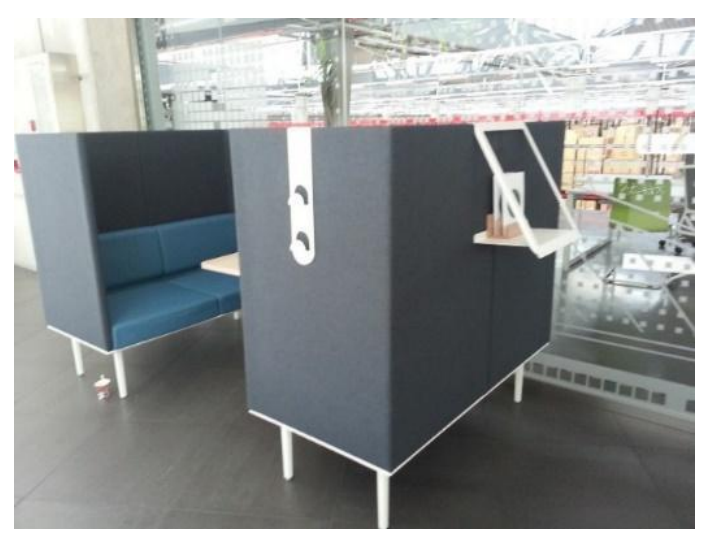

Figure 9. Sofa and table designed by the company ACTIU to insulate from noisy surroundings in open spaces [54].

Finally, in an education for sustainable development it is important to raise awareness about the negative effects of the noisy and loud society in which we live [26] and the benefits of tranquility and balance. In this sense, some schools request permission for holding activities that help relieve stress, encourage serenity and concentration. All members of the school community are invited to attend these sessions. They are extracurricular and take place during break-time or after school. Examples of these activities were found in IES La Torreta in Elche or IES Mediterrània in Benidorm.

\subsection{Conclusions}

Based on the results of this study, the following conclusions can be put forward:

- In the past, building design in learning spaces was not as influential as it is nowadays, at least concerning acoustic needs, since the classes were more teacher-centered and consequently more silent. 
- Nowadays, findings prove that classrooms do not meet the appropriate noise requirements to be able to complete cognitive assignments, which require concentration [55]. With regard to the question concerning physical space, are the classrooms acoustically conditioned (even for traditional methodologies)? Results of the surveys and interviews show that the conditions need to be improved. We suggest that planners, architects and engineers participate more closely with the school community in order to empathize and understand more about methodologies that are being implemented. Specific mention is the case of the planning of the music rooms or sport fields seen in Figures 6 and 7.

- About the questions regarding methodologies, can acoustic discomfort limit or slow down teachers' urge to implement innovative strategies? Are classrooms acoustically conditioned for implementing new methodologies? Findings from the interviews state that if, for example, moving furniture causes a noise that may bother colleagues or if there is reverberation, echo or disruption from outside, the teacher tends to implement activities that are more silent and easier to control. This case was mentioned specially by foreign language teachers.

- Concerning the question about health issues, does the need to battle background noise cause throat problems, temporary voice loss, and other physical, emotional or mental problems? There is no doubt to this question, whose response can be found in numerous articles worldwide, many of which have been cited in this paper. The investigation reveals that noise pollution and reverberation is a major discomfort for teachers and students. It produces irritability, lack of concentration, weariness, depression, headaches and so on. In students it may cause a drop in academic results, especially in mathematics or languages. In teachers, it can mean taking sick leave due to voice ailments. Therefore, findings of the research should have practical consequences for the design and/or refurbishment of schools [7,22,24].

- In the following explanation we find the response to the key question can acoustic comfort facilitate innovation and consequently help in the progress towards SDG? During our observation we have seen that progress towards an education for sustainable development is being achieved by implementing more participatory, active and student-based pedagogies. Many of these pedagogies tend to raise the noise level of classrooms. If we improve acoustic conditions, activities taking place in one room will not interfere or be a bother for users of adjacent rooms that may be writing exams or implementing tasks that require less noise tolerance. Teachers will feel free to choose their activities and teaching method as needed and not limited by the acoustic conditions of space. We believe this will help progress towards SDG and allow students to thrive in different learning environments.

- We are aware that improving the academic results and motivation of students and teachers and implementing new methodologies is a complex and challenging task that should not be simplified to an issue of space design. However, structural features of the classroom in particular and the school building in general are undoubtedly decisive.

- The most successful way to reach creative solutions is through a participatory approach that involves the whole school community as well as designers and planners. Viable solutions are possible for all different types of budgets, as has been indicated in point 4.1 .

- Finally, we consider it is essential to prepare a White Paper for the design of public high schools in Spain for the sake of moving towards sustainable development goals.

Author Contributions: Conceptualization, I.M., A.M.M. and J.N.P.; Methodology, I.M. and A.M.M.; Validation, A.M.M.; Formal Analysis, I.M. and J.N.P.; Investigation, I.M. and A.M.M.; Resources, I.M., A.M.M. and S.M.; Data Curation, A.M.M.; Writing-Original Draft Preparation, I.M. and A.M.M.; Writing-Review \& Editing, J.N.P. and S.M.; Supervision, A.M.M. and J.N.P.

Funding: This research received no external funding.

Conflicts of Interest: The authors declare no conflict of interest. 


\section{References and Notes}

1. Benayas, J.; Marcén, C.; Alba, D.; Gutiérrez, J. Educación Para la Sostenibilidad en España. Reflexiones y Propuestas. Fundación Alternativas y Red Española Para el Desarrollo Sostenible; Documento de Trabajo Opex No. 86/2017; Fundación Alternativas: Madrid, Spain, 2017.

2. Bascopé, M.; Perasso, P.; Reiss, K. Systematic Review of Education for Sustainable Development at an Early Stage: Cornerstones and Pedagogical Approaches for Teacher Professional Development. Sustainability 2019, 11, 719. [CrossRef]

3. Breiting, S.; Mayer, M.; Mogensen, F. Criterios de Calidad para Escuelas de EDS. Austrian Federal Ministry of Education, Science and Culture, Dept. V/11c 2005. Available online: https:/www.ensi.org/global/downloads/ Publications/211/QC-ESP.pdf (accessed on 3 February 2019).

4. Crampton, F.E. Spending on school infrastructure: Does money matter? J. Educ. Adm. 2009, 47, $305-322$. [CrossRef]

5. Woolner, P.; Hall, E. Noise in Schools: A Holistic Approach to the Issue. Int. J. Environ. Res. Public Health. 2010, 7, 3255-3269. [CrossRef] [PubMed]

6. Woolner, P.; Thomas, U.; Tiplady, L. Structural change from physical foundations: The role of the environment in enacting school change. J. Educ. Chang. 2018, 19, 223-242. [CrossRef]

7. Gilavand, A.; Jamshidnezhad, A. The Effect of Noise in Educational Institutions on Learning and Academic Achievement of Elementary Students in Ahvaz, South-West of Iran. Int. J. Pediatrics Mashhad 2016, 4, 1453-1463.

8. Guardino, C.A.; Fullerton, E. Changing Behaviors by Changing the Classroom Environment. Teach. Except. Child. 2016, 42, 8-13. [CrossRef]

9. Rantala, L.; Sala, E. Associations between Classroom Conditions and Teacher's Voice Production. Energy Procedia 2015, 78, 3120-3125. [CrossRef]

10. Guía de Diseño de Espacios Educativos. Proyecto conjunto del Ministerio de Educación con Unesco-Orealc. In Reforma Educativa Chilena: Optimización de la Inversión en Infraestructura Educativa; MINEDUC; UNESCO: Santiago, Chile, 1999.

11. Campell, C.; Brokmann, H.; Vugts, J.; Van Oorschot, E. Acoustic Impact on Effective Teaching and Learning Activities in Open Learning Spaces. In Proceedings of the Conference Proceedings Euronoise, Crete, Greece, 27-31 May 2018; pp. 1741-1748. Available online: http://www.euronoise2018.eu/docs/papers/293_ Euronoise2018.pdf (accessed on 21 March 2019).

12. Informe Anexo Memoria Dirección Fin De Curso IES Mediterrània 2006/07. Available online: http: //bit.ly/2YckjN3 (accessed on 21 March 2019).

13. Montiel, I.; Mayoral, A.M. Promoting Innovative Learning Spaces at Universidad Miguel Hernández. In ICERI 2018 Proceedings; IATED: València, Spain, 2018; pp. 4790-4797.

14. Video Produced by $2^{\circ}$ ESO Students in 2018 at IES Mediterrània, Benidorm, Spain. "Arquitects Help!". Available online: http://bit.ly/2Ycx6PA (accessed on 21 March 2019).

15. Ramli, N.H.; Ahmad, S.; Taib, M.Z.M.; Masri, M. Principals' Perception on Classroom Physical Environment. Procedia Soc. Behav. Sci. 2014, 153, 266-273. [CrossRef]

16. Allen, J. Building Evidence. In The 9 Foundations of a Healthy Building; Harvard T.H. Chan School of Public Health, Center for Health and Global Environment: Boston, MA, USA, 2017.

17. Halin, N. A Shield against Distraction from Environmental Noise. Ph.D. Thesis, Faculty of Engineering and Sustainable Development, University of Gävle, Gävle, Sweden, 6 August 2016.

18. Puglisi, G.; Cutiva, L.C.; Pavese, L.; Castellana, A.; Bona, M.; Fasolis, S.; Lorenzatti, V.; Carullo, A.; Burdorf, A.; Bronuzzi, F.; et al. Acoustic Comfort in High-school Classrooms for Students and Teachers. Energy Procedia 2015, 78, 3096-3101. [CrossRef]

19. Villarreal Cedillo, M.A.; Olivares, J.d.G. Espacios educativos y aprendizaje. In Programa Escuelas de Tiempo Completo en el Distrito Federal; Administración Federal de Servicios Educativos en DF: Mexico, Mexico, 2014; pp. 1-48.

20. Cheryan, S.; Ziegler, S.A.; Plaut, V.C.; Meltzoff, A.N. Designing Classrooms to Maximize Student Achievement. Policy Insights Behav. Brain Sci. 2014, 1, 4-12. [CrossRef]

21. Ariani, M.G.; Mirdad, F. The Effect of School Design on Student Performance. Int. Educ. Stud. 2015, 9, 175. [CrossRef] 
22. Nazneen, S.; Khan, S.; Ishtiaq, M.; Yousaf, S.; Shakoor, H. Effects of noise pollution on the health of exposed population and its threshold levels: A review. J. Med. Sci. Peshawar 2017, 25, 366-372.

23. Agencia Estatal Boletín Oficial del Estado 2007 REAL DECRETO 1367/2007, de 19 de Octubre, Por el Que se Desarrolla la Ley 37/2003, de 17 de Noviembre, del Ruido, en lo Referente a Zonificación Acústica, Objetivos de Calidad y Emisiones Acústicas. BOE. Available online: https:/www.boe.es/boe/dias/2007/10/23/pdfs/ A42952-42973.pdf (accessed on 21 March 2019).

24. Toyinbo, O. Indoor Environmental Quality, Pupil's Health and Academic Performance. Ph.D. Thesis, University of Eastern Finland, Kuopio, Finland, 20 December 2017.

25. Dreossi, R.C.F.; Momensohn-Santos, T. Noise and its interference over students in a classroom environment: Literature review. Pró Fono Rev. Atualização Científica 2005, 17, 251-258. [CrossRef]

26. Bulunuz, N.; Orbak, A.Y.; Mulu, N.; Tav, F. An Evaluation of Primary School Students' Views about Noise Levels in School. Int. Electron. J. Elem. Educ. 2017, 9, 725-740.

27. Ministerio de Educación de Perú. Guía de Diseño de Espacios Educativos-Acondicionamiento de locales escolares al nuevo modelo de Educación Básica Regular. Primaria y Secundaria; MINEDU: Lima, Perú, 2015; pp. 1-296.

28. Law 7/2002, Generalitat Valenciana. The Noise Pollution Protection Act. Available online: https://www.boe. es/buscar/pdf/2003/BOE-A-2003-613-consolidado.pdf (accessed on 3 December 2002).

29. Comparative Table of the Level of Sounds Expressed in A-Weighted Decibels (dB(A)). Available online: http://www.dba-acustica.com/blog/tabla-comparativa-de-decibelios/ (accessed on 2 May 2019).

30. Dockrell, J.E.; Shield, B.M. Acoustical barriers in classrooms: The impact of noise on performance in the classroom. Br. Educ. Res. J. 2006, 32, 509-525. [CrossRef]

31. Sârbu, I.; Sebarchievici, C. Aspects of indoor environmental quality assessment in buildings. Energy Build. 2013, 60, 410-419. [CrossRef]

32. Ubillos, S.; Centeno, J.; Iba, J. Protective and Risk Factors Associated with Voice Strain Among Teachers in Castile and Leon, Spain: Recommendations for Voice Training. J. Voice Off. J. Voice Found. 2015, 29, 1-12. [CrossRef] [PubMed]

33. ORDEN 38/2017, de 4 de octubre, de la Conselleria de Educación, Investigación, Cultura y Deporte, por la que se regula la evaluación en Educación Secundaria Obligatoria, en Bachillerato y en las enseñanzas de la Educación de las Personas Adultas en la Comunitat Valenciana. [2017/8755]).

34. López, S. Esencia. Diseño de Espacios Educativos: Aprendizaje y Creatividad; Luis Vives (Edelvives): Zaragoza Spain, 2018; pp. 1-364.

35. Nair, P. Blueprint for Tomorrow: Redesigning Schools for Student-Centered Learning; Harvard Education Press: Cambridge, MA, USA, 2014.

36. Neuman, D. Building Type Basics for College and University Facilities; John Wiley \& Sons: Hoboken, NJ, USA, 2013.

37. Kaushik, A.; Elsarrag, E.; Mazroei, A.; Al horr, Y.; Arif, M.; Katafygiotou, M. Impact of indoor environmental quality on occupant well-being and comfort: A review of the literature. Int. J. Sustain. Built Environ. 2016, 5, $1-11$.

38. Huang, L.; Zhu, Y.; Ouyang, Q.; Cao, B. A study on the effects of thermal, luminous, and acoustic environments on indoor environmental comfort in offices. Build. Environ. 2012, 49, 304-309. [CrossRef]

39. Tonhauser, P. Design Thinking Workshop: The 12 Indispensable Elements for a Design Thinking Workshop. 2015. e-book. Berlin. Available online: http://publicaciones.umh.es/docview/1786515625?accountid=28939 (accessed on 21 March 2019).

40. Prud'homme, P. The culture of design thinking for innovation. J. Innov. Manag. 2017, 5, 56-80. Available online: http://publicaciones.umh.es/docview/1957729439?accountid=2893 (accessed on 21 March 2019). [CrossRef]

41. Vargas, B.A. Educación para el desarrollo sostenible (EDS) y arquitectura escolar. el espacio como reactivo del modelo pedagógico. Bordón. Rev. Pedagog. 2015, 68, 145-163. [CrossRef]

42. García, Á.; Muñoz, J.M. Pedagogía de los espacios. Esbozo de un horizonte educativo para el siglo XXI. Rev. Española Pedagog. 2004, 228, 257-278.

43. Departamento de Educación Ambiental. Guía del profesorado Educar para vivir sin ruido; Ayuntamiento de Mdrid: Madrid, Spain, 2005; pp. 1-64.

44. Camino, M.J. Project Work with $1^{\circ}$ ESO Students. 2013. Available online: https://www.mariajesusmusica. com/inicio/la-contaminacin-acstica-de-nuestro-ies-una-tarea-para-trabajar-todas-las-competenciasbsicasandhttp://www.educacontic.es/blog/la-contaminacion-acustica-en-nuestros-centros-educativos-unarealidad (accessed on 10 April 2019). 
45. Gobierno de España. Ley 38/1999, de Ordenación de la Edificación. Boletín Of. Del Estado 1999, 266, 38925-38934.

46. Choi, S.; Guerin, D.A.; Kim, H.-Y.; Brigham, J.K.; Bauer, T. Indoor Environmental Quality of Classrooms and Student Outcomes: A Path Analysis Approach. J. Learn. Spaces 2014, 2, 2013-2014.

47. Mihai, T.; Iordache, V. Determining the Indoor Environment Quality for an Educational Building. Energy Procedia 2015, 85, 566-574. [CrossRef]

48. U.S. Green Building Council (USGBC). Guía de Conceptos Básicos de Edificios Verdes y LEED. 2009. Available online: http://www.spaingbc.org/files/BD+C_StudyGuide-ES.pdf (accessed on 21 March 2019).

49. GORD. Global Sustainability Assessment System (GSAS). 2019. Available online: http://www.gord.qa/trustgsas-resource-center-overview (accessed on 21 March 2019).

50. Gobierno de España. Código Técnico de Edificación. 2006. Available online: https://www.codigotecnico.org/ index.php/menu-documentoscte.html (accessed on 24 April 2019).

51. Trombetta Zannin, P.H.; Zanardo Zwirtes, D.P.; Marcon Passero, C.R. Assessment of Acoustic Quality in Classrooms Based on Measurements, Perception and Noise Control. In Noise Control, Reduction and Cancellation Solutions in Engineering; Books on Demand: Norderstedt, Germany, 2012.

52. Mora, F. Neuroeducación: Sólo Se Puede Aprender Aquello Que Se Am.; Alianza Editorial: Madrid, Spanish, 2013.

53. Dance, A. Science and Culture: The brain within buildings. Proc. Natl. Acad. Sci. USA 2017, 114, 785-787. [CrossRef] [PubMed]

54. Furniture Pictures for Schools and Offices. Available online: https://www.actiu.com/ (accessed on 21 March 2019).

55. Chiang, C.-M.; Lai, C.-M. Acoustical environment evaluation of Joint Classrooms for elementary schools in Taiwan. Build. Environ. 2008, 43, 1619-1632. [CrossRef]

(C) 2019 by the authors. Licensee MDPI, Basel, Switzerland. This article is an open access article distributed under the terms and conditions of the Creative Commons Attribution (CC BY) license (http://creativecommons.org/licenses/by/4.0/). 